\title{
Konsumsi Ekstrak Secang (Caesalpinia sappan L.) Terhadap Volume Urin Tikus Putih Jantan Galur Spraque Dawley
}

Penulis

Afiliasi
Pertamawati*, Sriningsih, Fahri Fahrudin, Julham Efendi

Pusat Teknologi Farmasi dan Medika - Laboratorium Pengembangan Teknik Industri Agro \& Biomedika, Badan Pengkajian dan Penerapan Teknologi

\section{Kata Kunci \\ ? ekstrak secang \\ $\partial$ volume urin \\ $\partial$ tikus putih}

Diterima 7 September 2015 Direvisi 10 Juni 2016 Disetujui 15 November 2017

*Penulis Koresponding Pertamawati Gedung 610-611 Tlp./ Fax : 021-7560707

Kawasan PUSPIPTEK, Serpong Banten

pertamawatikartakusumah@g mail.com

\section{ABSTRAK}

Secara empiris secang (Caesalpinia sappan L.) dimanfaatkan sebagai bahan untuk mengatasi penyakit, namun bagaimana pengaruhnya terhadap pengeluaran urin belum diketahui. Penelitian ini bertujuan untuk mengetahui pengaruh konsumsi ekstrak secang terhadap pengeluaran urin. Percobaan dilakukan terhadap hewan coba tikus putih jantan galur Spraque dawley dengan sampel uji ekstrak etanol $96 \%$ kulit kayu secang. Hewan coba dibagi dalam 7 kelompok, masing-masing terdiri dari 6 ekor, yaitu kelompok normal, kelompok positif (Furosemide $10 \mathrm{mg} / 200 \mathrm{~g} \mathrm{BB}$ ), kelompok negatif (air $2 \mathrm{ml} / 200 \mathrm{~g} \mathrm{BB})$, kelompok sampel uji dosis I (62,5 mg/kg BB), dosis II (125mg/kg BB), dosis III ( $250 \mathrm{mg} / \mathrm{kg} \mathrm{BB})$ dan dosis IV $(500 \mathrm{mg} / \mathrm{kg} \mathrm{BB})$, tigapuluh menit setelah pemberian sampel uji, hewan coba diberi air minum $4 \mathrm{ml} / 200 \mathrm{~g}$ BB dilakukan melalui sonde lambung, selanjutnya hewan coba dimasukkan ke dalam kandang metabolit selama 16 jam (overnight). Hewan coba dengan dosis II menghasilkan volume urin paling besar $(8.00 \mathrm{~mL})$ yaitu hampir dua kali lipat dibandingkan urin yang dihasilkan oleh kelompok normal $(4.50 \mathrm{~mL})$ Volume urin berkurang jika konsumsi ekstrak secang bertambah pada dosis III dan IV. Disimpulkan bahwa hewan coba yang diberi ekstrak kulit secang dengan dosis $125 \mathrm{mg} / \mathrm{kg}$ BB (dosis II) rata-rata mampu mengeluarkan urin lebih banyak daripada hewan coba dalam kelompok lainnya.

\section{PENDAHULUAN}

Indonesia merupakan salah satu negara mega diversity untuk tumbuhan obat di dunia. Wilayah hutan tropika Indonesia memiliki keanekaragaman hayati tertinggi ke-2 di dunia setelah Brasil. Dari 40.000 jenis flora yang ada di dunia sebanyak 30.000 jenis dijumpai di Indonesia dan 940 jenis di antaranya diketahui berkhasiat sebagai obat yang telah dipergunakan dalam pengobatan tradisional secara turun-temurun oleh berbagai etnis di Indonesia. Jumlah tumbuhan obat tersebut meliputi sekitar $90 \%$ dari jumlah tumbuhan obat yang terdapat di kawasan Asia (CI 1997; WWF 2012). 
Penggunaan obat tradisional (jamu) di Indonesia pada hakekatnya merupakan bagian kebudayaan bangsa Indonesia. Keuntungan dari penggunaan jamu pada prinsipnya adalah efek samping yang relatif kecil dibandingkan obat modern. Meskipun secara empiris jamu mampu menyembuhkan berbagai macam penyakit, tetapi khasiat dan kemampuannya belum banyak dibuktikan secara ilmiah maupun klinis. Selain itu, belum banyak diketahui senyawa kimia apa yang bertanggung jawab terhadap khasiat jamu tersebut (Wijayakusuma 2002).

Salah satu tanaman yang banyak digunakan dalam pengobatan tradisional adalah secang (Caesalpinia sappan L,). Kayu secang memiliki khasiat sebagai pengelat (astringensia). Kandungan utamanya adalah brazilin, yakni zat warna merah-sappan, asam tanat, dan asam galat. Simplisia kayu secang berupa irisan atau keping-keping kecil kayu ini dikenal sebagai Sappan lignum dalam sediaan FMSo (Formularium Medicamentorum Soloensis) (Sutrisno 1974). Brazilin dari kayu secang teruji secara ilmiah bersifat antioksidan, antibakteri, anti-inflamasi, antiphotoaging, hypoglycemic (menurunkan kadar lemak), vasorelaxant (merelaksasi pembuluh darah), hepatoprotective (melindungi hati) dan anti-acne (anti jerawat) (Nirmal et al. 2015). Ekstrak kayu secang juga ditengarai berkhasiat anti-tumor, anti-virus, immunostimulant dan lain-lain (Badami et al., 2004) Secara tradisional, potongan-potongan kayu secang biasa digunakan sebagai campuran bahan jamu di Jawa. Di samping itu, kayu secang adalah salah satu bahan pembuatan minuman penyegar khas Yogyakarta selatan (wedang secang dan wedang uwuh) (Syifa 2015).

Secang juga telah lama dikenal sebagai bahan ramuan untuk mengobati berbagai penyakit, seperti sifilis, batuk darah, dan radang penelitian yang dilakukan oleh Sugiyanto et al. (2013) di Fakultas Farmasi Universitas Gadjah Mada, juga mengungkapkan, secang memiliki kemampuan antioksidan, antikanker, memperlancar peredaran darah, dan melegakan pernapasan. Penelitian yang telah dilakukan oleh Pertamawati et al pada tahun 2014 memperlihatkan bahwa secang juga mampu mengatasi masalah diuretikun (Pertamawati et al. 2014).

Diuretika adalah senyawa yang dapat menyebabkan ekskresi urin yang lebih banyak. Jika pada peningkatan ekskresi garam-garam, maka diuretika ini dinamakan saluretika atau natriuretika (diuretika dalam arti sempit) (Mutschler 1991).

Tujuan percobaan ilmiah yang dilaksanakan secara preklinis ini ialah untuk mengetahui kemampuan atau pengaruh konsumsi ekstrak kulit kayu secang (Caesalpinia sappan L.) dalam memperbaiki kemampuan pengeluaran urin hewan coba tikus putih jantan galur Spraque dawley, sampel diberikan secara oral melalui sonde lambung untuk mendapatkan informasi dosis efektif dari sampel uji. Pengolahan data yang diperoleh dilakukan secara metoda statistik Analisis Varian dan untuk menguji perbedaan nilai ratarata antar 2 perlakuan digunakan metode Uji Wilayah Berganda Duncan. Hasil percobaan diharapkan dapat memberikan informasi dalam meningkatkan kesehatan dengan mengembangkan obat herbal terstandar (OHT) secara tradisional sehingga dapat dimanfaatkan berdasarkan landasan ilmiah. Penelitian ini dilaksanakan pada bulan Maret sampai dengan bulan Mei tahun 2014 di laboratorium Pusat Teknologi Farmasi dan Medika - LAPTIAB - TAB - BPPT.

\section{METODE}

\section{Animals Bahan}

Ekstrak etanol kulit kayu secang; Tikus putih jantan galur Spraque Dawley; CMC Na 5\%, (Natrium karboksilmetil selulosa); Furosemide (generik), akuades.

Alat

Timbangan hewan, kandang tikus beserta tempat makan dan minum, sonde oral, blender, magnetic stirer, evaporator, kertas saring, tissue, timbangan analitik, peralatan gelas.

\section{Pembuatan simplisia}

Pembuatan simplisia kulit kering kayu secang melalui tahapan sortasi basah, pencucian, perajangan, pengeringan, sortasi kering, dan penepungan (penggilingan dan pengayakan). Kulit kayu secang diperoleh dari Balai Pengkajian Teknologi Pertanian (BPTP) Lembang.

\section{Ekstraksi}

Simplisia serbuk kulit kayu secang kering (400 gram) diekstraksi dengan metode maserasi, menggunakan pelarut etanol $96 \%$ dengan perbandingan $1: 10$ selama 2x1jam, sehingga diperoleh ekstraknya. Ekstrak yang diperoleh dievaporasi sampai diperoleh ekstrak kental. 
Selanjutnya, ektrak kental tersebut disimpan dalam lemari pendingin sampai saat digunakan sebagai sampel uji (DepKes RI DitJen POM 2000; Harborne 1996).

\section{Penapisan Fitokimia}

Penapisan fitokimia simplisia dimaksudkan untuk mengetahui kandungan golongan senyawa dalam simplisia. Penapisan fitokimia dilakuan berdasarkan teori dan metode Fransworth (1986) dan Harborne (1996).

\section{Persiapan hewan coba}

Hewan coba yang digunakan adalah tikus putih jantan galur Spraque dawley berusia 2-3 bulan dengan berat badan sekitar 150-200 gram, diaklimatisasi selama satu minggu agar dapat menyesuaikan diri dengan lingkungannya, mengontrol kesehatan dan berat badan. Hewan uji dipilih sebanyak 42 ekor tikus putih jantan secara acak untuk dibagi menjadi 7 kelompok, tiap kelompok terdiri dari 6 ekor. (Disetujui oleh Komite Etik Penelitian Kesehatan Fakultas Kedokteran Rumah Sakit Cipto Mangunkusumo No. 163/H2.F1/ETIK/2014 tanggal 24 Maret 2014).

\section{Persiapan sampel uji}

Ekstrak kental kulit kayu secang dijadikan sampel uji yang diberikan terhadap hewan coba tikus putih jantan sesuai dengan dosis yang telah ditentukan.

\section{Pembuatan sampel uji}

a. Pembuatan suspensi sampel uji.

Sebanyak 2 gram sampel uj dimasukkan ke dalam

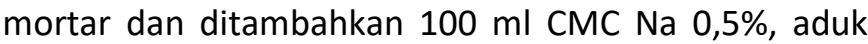
rata sampai homogen. Campuran tersebut diberikan kepada hewan coba dengan konsentrasi $2 \mathrm{ml} / 200 \mathrm{~g} \mathrm{BB}$

b. Pembuatan suspensi Furosemide.
Satu tablet Furosemide setara dengan $40 \mathrm{mg}$, dilarutkan dengan CMC 0,5\% sehingga diperoleh perhitungan $10 \mathrm{mg}$ untuk berat badan hewan coba 200g.

\section{Pelaksanaan Percobaan}

Pada percobaan ini digunakan rancangan acak kelompok, hewan coba yang digunakan berjumlah 42 ekor yang dibagi secara acak menjadi tujuh kelompok perlakuan dan tiap kelompok terdiri dari enam ekor, yang dibedakan berdasarkan pemberian bahan (sampel) uji (Tabel 1).

Setiap hewan coba dalam setiap kelompok mendapat perlakuan sebagai berikut :

- Diberi air minum 4ml/200g BB secara oral

- Dimasukan ke dalam kandang metabolit selama 16 jam (overnight).

- Diberi perlakuan setelah masa puasa sesuai dosis masing-masing secara oral sekali sehari. Hewan coba dalam kelompok normal diberi larutan CMC-Na $0,5 \%$ sebanyak $1 \mathrm{ml} / 200 \mathrm{~g}$ BB per oral, hewan coba dalam kelompok negatif diberi larutan CMC-Na 0,5\% sebanyak $1 \mathrm{ml} / 200 \mathrm{~g}$ BB dan air $4 \mathrm{ml} / 200 \mathrm{~g}$ BB secara per oral, dan hewan coba dalam kelompok positif diberi Furosemide $10 \mathrm{mg} / 200 \mathrm{~g}$ BB dan air $4 \mathrm{ml} / 200 \mathrm{~g}$ BB secara per oral.

- Urin yang keluar ditampung, diukur volumenya dan diperhatikan warna urine secara manual.

\section{Pengolahan data volume urine}

Urine yang diperoleh ditabulasi dan dianalisis. Analisis data dimaksudkan untuk melihat ada tidaknya perbedaan urine setiap hewan coba dalam masingmasing kelompok pada satu kali pengambilan. Pengolahan data menggunakan metode statistika Analisis Varian dan untuk menguji perbedaan nilai ratarata antar 2 perlakuan digunakan metode uji Wilayah Berganda Duncan.

Tabel 1. Pembagian Kelompok Perlakuan

Kelompok

Normal

Negatif

Positif

Dosis I

Dosis II

Dosis III

Dosis IV

\section{Perlakuan}

Diberi larutan CMC-Na 0,5\% sebanyak $1 \mathrm{ml} / 200 \mathrm{~g} \mathrm{BB}$

Diberi larutan CMC-Na 0,5\% sebanyak $1 \mathrm{ml} / 200 \mathrm{~g}$ BB dan air 4ml/200g BB

Diberi Furosemide $10 \mathrm{mg} / 200 \mathrm{~g}$ BB dan air $4 \mathrm{ml} / 200 \mathrm{~g}$ BB

Diberi sampel uji 62,5mg/kg BB dan air 4ml/200g BB

Diberi sampel uji $125 \mathrm{mg} / \mathrm{kg}$ BB dan air 4ml/200g BB

Diberi sampel uji $250 \mathrm{mg} / \mathrm{kg}$ BB dan air $4 \mathrm{ml} / 200 \mathrm{~g} B \mathrm{~B}$

Diberi sampel uji $500 \mathrm{mg} / \mathrm{kg}$ BB dan air $4 \mathrm{ml} / 200 \mathrm{~g} B \mathrm{~B}$
Jumlah Tikus

6

6

6

6

6

6

6 


\section{HASIL DAN PEMBAHASAN}

\section{Ekstraksi}

Hasil ekstraksi sebanyak 400 gram simplisia kulit kayu secang bubuk yang dilakukan dengan cara maserasi dengan pelarut etanol 96\% dengan perbandingan 1 : 10 selama 1 jam sebanyak 2 kali, memberikan hasil berupa ekstrak yang dikentalkan dengan alat evaporator sehingga menghasilkan ekstrak kental dengan berat $6.97 \mathrm{~g}$.

\section{Penapisan fitokimia}

Berdasarkan hasil pemeriksaan penapisan fitokimia ekstrak kental kulit kayu secang, terlihat bahwa ekstrak kental kulit kayu secang mengandung kadar terpenoid tinggi $(+++)$, kadar fenol tinggi $(+++)$,kadar triterpenoid cukup $(++)$, kadar flavonoid cukup $(++)$, kadar alkaloid cukup $(++)$ dan kadar saponin sedikit $(+)$, namun tidak mengandung steroid dan tannin (-) seperti tertulis dalam Tabel 2. Menurut Widowati (2011), hasil uji fitokimia ekstrak secang mengandung senyawa terpenoid dan fenol tetapi tidak mengandung senyawa steroid dan tannin. Ekstrak kayu secang mengandung kadar total fenol ekivalen EGC $849.11 \mu \mathrm{g} / \mathrm{mg}$ dan ekivalen ECG $825.11 \mu \mathrm{g} / \mathrm{mg}$. Selain itu, ekstrak kayu secang memiliki aktivitas antioksidan tinggi yaitu 80.46 $89.13 \%$.

\section{Berat Badan}

Berat badan adalah hasil pengaturan kontrol neural dan hormonal yang secara substansial mengatur keseimbangan antara pemasukan dan pengeluaran energi. Sistem regulatori yang kompleks ini dibutuhkan karena sedikit ketidakseimbangan antara pemasukan dan penggunaan energi akan memberi efek yang cukup signifikan pada berat badan (Fauci et al. 2008).

Pada awal perlakuan, pemberian sampel uji ekstrak kayu secang berat badan hewan coba cenderung rendah, dan semakin lama pemberian ekstrak secang semakin meningkatkan berat badan hewan coba. Ketika jumlah energi yang masuk ke dalam tubuh (dalam bentuk makanan) melebihi jumlah energi yang digunakan, berat badan akan meningkat, dan kebanyakan dari energi yang berlebih akan disimpan dalam bentuk lemak. Oleh karena itu, adipositas yang berlebihan (obesitas) disebabkan oleh konsumsi energi yang berlebihan dibandingkan dengan penggunaannya. Lokasi penyimpanan lemak yang utama adalah pada jaringan subkutan dan pada rongga intraperitoneal, walaupun hati dan jaringan lainnya didalam tubuh juga terkadang menyimpan lemak dalam jumlah yang signifikan (Guyton dan Hall 2006). Kenaikan berat badan ini tampak pada semua kelompok hewan coba dalam percobaan, seperti terlihat dalam Gambar 1.

\section{Volume Urin}

Perlakuan pemberian sampel uji mampu meningkatkan kemampuan pengeluaran urin tiap hewan coba dalam kelompoknya. Volume urin hewan coba dengan perlakuan pemberian sampel uji dosis 2 lebih banyak daripada volume urin hewan coba dalam

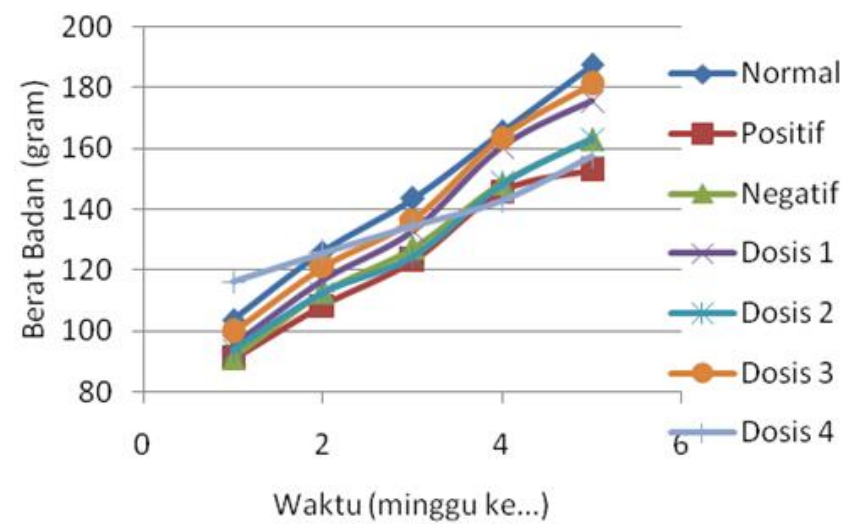

Gambar 1 Bobot badan hewan coba sesuai perlakuan

Tabel 2. Hasil Penapisan Fitokimia Ekstrak Kayu Secang

\begin{tabular}{cccccccc}
\hline \multicolumn{7}{c}{ Hasil Penapisan Fitokimia } \\
\hline Terpenoid & Fenol & Triterpenoid & Flavonoid & Alkaloid & Saponin & Steroid & Tannin \\
\hline+++ & +++ & ++ & ++ & ++ & + & - & - \\
\hline
\end{tabular}

Keterangan : +++ : kadar tinggi, ++ : kadar cukup, + : kadar sedikit, - : tidak mengandung 
kelompok positif, yaitu sebanyak $8.00 \mathrm{ml}$, seperti tertulis dalam Tabel 3.

Hasil percobaan yang diperoleh memperlihatkan bahwa ekstrak kulit kayu secang mampu memperbaiki kemampuan pengeluaran urin hewan coba.

Tabel 3. Rataan volume urin hewan coba dalam perlakuan

\begin{tabular}{lc}
\hline \multicolumn{1}{c}{ Kelompok \& perlakuan } & $\begin{array}{c}\text { Rataan volume } \\
\text { Urin (ml) }\end{array}$ \\
\hline Normal & $4.50^{\text {(cd) }}$ \\
Positif (Furosemide 10mg/200g BB) & $5.00^{\text {(bc) }}$ \\
Negatif (aquades 2ml/200g BB) & $4.25^{\text {(d) }}$ \\
Dosis I (62,5ml/kg BB) & $4.50^{\text {(cd) }}$ \\
Dosis II (125ml/kg BB) & $8.00^{(\mathrm{a})}$ \\
Dosis III (250ml/kg BB) & $5.75^{\text {(b) }}$ \\
Dosis IV (500ml/kg BB) & $5.50^{\text {(b) }}$ \\
\hline
\end{tabular}

Keterangan : Angka-angka yang diikuti oleh huruf sama pada waktu pengamatan yang sama menunjukkan tidak berbeda nyata pada taraf $5 \%$ uji DMRT

\section{SIMPULAN}

Berdasarkan pada penelitian ini, dapat disimpulkan bahwa ekstrak kayu secang (Caesalpinia sappan L.) mampu memperbaiki kemampuan pengeluaran urin hewan coba tikus putih jantan galur Spraque dawley., sedangkan perlakuan pemberian sampel uji dosis II (125 mg/200 g BB) mampu meningkatkan pengeluaran urin hewan coba dengan volume terbanyak $(8 \mathrm{ml})$, dan pengujian secara ilmiah yang dilakukan secara preklinis terhadap hewan coba tikus putih jantan galur Spraque Dawley menguatkan pengetahuan masyarakat yang secara empiris telah memanfaatkan herbal secang sebagai peluruh urin.

\section{UCAPAN TERIMA KASIH}

Ucapan terima kasih disampaikan kepada Kementerian Riset dan Teknologi RI. yang telah memberikan bantuan dana penelitian SINas 2014 dan Pimpinan Pusat TFM-TAB - BPPT yang memfasilitasi pelaksanaan dan penyelesaian penelitian.

\section{DAFTAR PUSTAKA}

Badami S, Moorkoth S, Suresh B. 2004. Caesalpinia sappan a medical and dye yielding plant. Natural Product Radiance. 3(2):75-82

[CI] Conservation International. 1997. Megadiversity. New York (USA).
DepKes RI DitJen POM. 2000. Parameter Standar Umum Ekstrak Tumbuhan Obat. Jakarta (ID): Direktorat Jenderal Umum Pengawasan Obat dan Makanan.

Fauci AS, Kasper DL, Longo D, Braunwald E, Hauser SL, Loscalzo J. 2008. Obesity. In : Harisson's Manual Of Medicine 17th Edition. USA : The McGraw-Hill Companies.

Fransworth NR. 1986. Biological and Phytochemical Screening of Plants, Journal of Pharmaceutical Science. 55(3):225-276.

Harborne JB. 1996. Metode Fitokimia. Ed. ke-2. Kosasih Padmawinata, penerjemah. Terjemahan dari: Phytochemical Methods. Bandung (ID): Institut Teknologi Bandung.

Guyton AC, Hall JE. 2006. Buku Ajar Fisiologi Kedokteran. Edisi 11. Irawati, Ramadani D, Indriyani $F$, penerjemah. Jakarta (ID): Penerbit Buku Kedokteran EGC.

Komite Etik Penelitian Kesehatan Fakultas Kedokteran Rumah Sakit Cipto Mangunkusumo No. 163/H2.F1/ETIK/2014.

Mutschler E. 1991. Dinamika obat Farmakologi dan Toksikologi. Bandung (ID): Institut Teknologi Bandung.

Nirmal, NP, Rajput MS, Prasad RGSV, Ahmad M. 2015. Brazilin from Caesalpinia sappan heartwood and its pharmacological activities: A review. Asian Pacific Journal of Tropical Medicine. 8(6):421-430.

Pertamawati, Nuralih, Fahrudin F. 2014. Ekstrak Secang Sebagai Bahan Diuretikum (Percobaan Terhadap Tikus Putih Jantan Galur Spraque Dawley). AlKauniyah Jurnal Biologi. 7(2):89-93.

Sugiyanto RN, Putri SR, Damanik FS, Sasmita GMA, 2013. Aplikasi kayu secang (Caesalpinia sappan L.) dalam upaya prevensi kerusakan DNA akibat paparan zat potensial karsinogenik melalui MNPCE assay. Yogyakarta (ID): Universitas Gajah Mada

Sutrisno B. 1974. Ihtisar Farmakognosi, Ed. IV: 122. Jakarta (ID): Pharmascience Pacific.

Syifa TH. 2015. Resep Wedang Uwuh Khas Yogyakarta yang Menyehatkan.[Diunduh 9 Juni 2016]. Tersedia pada: http://www.butania.com/2015/11/resepwedang-uwuh.html Resep wedang uwuh khas Yogyakarta yang menyehatkan.

Widowati W. 2011. Uji Fitokimia dan Potensi Antioksidan Ekstrak Etanol Kayu Secang (Caesalpinia sappan L.). Jurnal Kedokteran Maranatha. 11(1):23-31. 
Wijayakusuma H. 2002 Tumbuhan Berkhasiat Obat Indonesia. Rempah, Rimpang dan Umbi. Jakarta (ID): Prestasi Instan Indonesia.
[WWF] World Wide Fund for Nature. 2012. Living Planet Report 2012. Netherlands (NL). 